\title{
PENERAPAN FITUR ADAPTIVE MULTI RATE (AMR) PADA JARINGAN GSM
}

\author{
Abdusy Syarif'; Ahmad Fachril ${ }^{2}$ \\ 1,2 Teknik Informatika, Fakultas Teknologi Industri, Universitas Mercu Buana, \\ Jln. Raya Meruya Selatan, Kembangan, Jakarta, 11650 \\ abdusyarif@mercubuana.ac.id; de_la_rocha2@yahoo.com
}

\begin{abstract}
Adaptive Mutlirate (AMR) is a feature that plays an important role in the efficiency of use of cell/voice channels and GSM networks in overall and it can improve sound quality dynamically based on actual measurements (real time) between Mobile Station (MS) and Base Transmitter Station (BTS). Resources used as analytical parameters are SQI (Speech Quality Index), MOS (Mean Opinion Score) and the sound quality on the network without and with AMR. Measurements using Test Equipment Mobile System (TEMS) while locking devices to the single channel and comparing them between the two types of network. Based on test results it is obtained that with voice channels with AMR can increase the value of SQI approximately $40 \%$ for fullrate channels and about $60 \%$ for half-rate channels producing a remarkable (excellent) level, with research and further measuring it is expected to produce better and more perfect sound quality.
\end{abstract}

Kata kunci: AMR, SQI, GSM network

\section{ABSTRAK}

Adaptive Mutlirate (AMR) merupakan suatu fitur yang memegang peranan penting didalam efisiensi penggunaan cell/kanal suara (voice) dan jaringan GSM secara keseluruhan serta dapat meningkatkan kualitas suara secara dinamik berdasarkan hasil pengukuran secara nyata (real-time) antara Mobile Station (MS) dan Base Transmitter Station (BTS). Sumber daya yang dijadikan parameter analisis adalah SQI (Speech Quality Index), MOS (Mean Opinion Score) dan kualitas suara yang dihasilkan pada jaringan tanpa AMR dan dengan AMR. Pengukuran menggunakan Test Equipment Mobile System (TEMS) dengan mengunci alat tersebut kepada satu kanal dan membandingkannya antara kedua jenis jaringan tersebut. Berdasarkan hasil pengujian diperoleh kanal suara dengan AMR dapat menaikan nilai SQI sekitar 40\% untuk kanal fullrate dan sekitar 60\% untuk kanal halfrate menjadi tingkat luar biasa (excellent), dengan penelitian dan pengukuran yang lebih lanjut diharapkan dapat menghasilkan kualitas suara yang lebih baik dan lebih sempurna.

Kata kunci: AMR, SQI, jaringan GSM

\section{PENDAHULUAN}

Komunikasi sudah menjadi kebutuhan masyarakat pada era informasi sekarang ini. Dalam meningkatkan service yang terbaik kepada pelanggan, masing-masing penyedia jasa telekomunikasi berlomba-lomba dalam memuaskan costumer/ pelanggan dalam menyediakan fitur, layanan suara yang jernih, dan telpon tiada putus (drop call). Untuk mendapatkan layanan suara yang baik, jernih dan berkualitas tinggi, operator penyedia jasa telekomunikasi menggunakan fitur Adaptive Multi Rate (AMR). Fitur ini dapat meningkatkan kinerja dengan sasaran peningkatan Speech Quality Index (SQI) dan membersihkan gangguan (noise) akibat interferensi.

Adapun pokok permasalahan yang akan dibahas pada penelitian ini mengenai rendahnya kualitas suara akibat dari error rate yang terdapat pada sistem jaringan GSM serta optimalisasi dalam penanganan C/I (Carrier per Interference). Tujuan dari penelitian ini adalah untuk menganalisis bagaimana fitur AMR dapat meningkatkan kinerja dan skalabilitas pada jaringan GSM yang sudah menerapkan AMR serta membandingkannya dengan jaringan GSM tanpa AMR. Adapun manfaat yang didapatkan dalam penerapan fitur Adaptive Multirate (AMR) pada jaringan komunikasi GSM ini terhadap peningkatan kualitas suara dan penambahan kapasitas pada jaringan GSM serta penanganan error rate yang disebabkan interferensi.

\section{METODE PENELITIAN}

Metode yang digunakan dibagi menjadi 3 tahap, yaitu (1) Metode studi literatur. Studi literatur yang dilakukan adalah pustaka pendukung perancangan penelitian ini termasuk fungsi AMR pada BSC, MSCe, end-user device dan sistem pengkodean pada kanal suara. Pengumpulan informasi-informasi ini bersumber dari buku, internet, majalah, artikel dan sebagainya yang dibutuhkan untuk penelitian ini; (2) Metode analisis. Tahapan-tahapan dari analisis adalah mencari fungsi-fungsi dari sistem pengkodean kanal suara yang optimal dalam penggunaannya, termasuk fungsi additional modul perangkat lunak dan perangkat keras pada network element yang terkait; menggunakan arsitektur jaringan yang berbeda untuk membandingkan hasil penerapan dan performansi yang didapat dalam penggunaan kanal suara pada jaringan GSM; dan perancangan fitur AMR pada perangkat keras GSM di semua Network Element yang terkait; (3) Metode pengujian dan pengukuran. Tahapantahapan dari pengujian adalah tahap ini melakukan penerapan dan pengkuran terhadap jaringan yang telah diterapkan fitur AMR dan tanpa fitur AMR menggunakan Test Equipment Mobile System (TEMS); pengukuran network yang menggunakan AMR diukur dari nilai Speech Quality Index (SQI) selama active call dibandingkan dengan network tanpa AMR; dan pengujian dilakukan untuk melihat kemampuan tingkat efesiensi jaringan dalam penggunaan kanal suara. 


\section{Analisis Sistem}

AMR adalah fitur pada BSC ERICSSON release 10 , dalam proses pengkodean kanal dan suara untuk Halfrate dan Fullrate. Dengan mengadaptasikan perubahan pengkodean pada saluran radio agar meningkatnya kualitas suara. Konsep dasar dari AMR ini adalah memberikan lebih banyak channel coding pada saat C/I rendah, dan sebaliknya akan meningkatkan speech coding dan mengurangi channel coding pada C/I tinggi.

Fitur AMR menawarkan kualitas suara yang bagus untuk pengguna AMR mobile di network GSM. Tingginya kualitas suara ini juga diperkuat oleh bagusnya kualitas sinyal pada batas cell, sehingga dapat memperluas coverage area. Interference yang selalu menjadi masalah dalam cell-planner juga dapat diatasi oleh AMR karena AMR dapat mentolerir lebih banyak interferenece daripada speech codec yang lama. Ini membuat traffic lebih tinggi dan menuju kapasitas yang lebih besar

Peningkatan speech quality dibagi menjadi 2 bagian dan pembagian ini yang membuat banyak operator sangat tertarik untuk menerapkan fitur ini. Peningkatan yang pertama adalah pada kanal Fullrate atau biasa disebut Robust FR. Kanal Robust FR yang menyediakan speech quality yang tinggi pada saat $\mathrm{C} / \mathrm{I}$ rendah atau interference tinggi karena pada saat kanal FR diberikan network akan memberikan error correction yang terampung dalam channel coding sehingga dapat membuat noise yang dihasilkan oleh interference dapat berkurang dan membuat speech quality tinggi pada saat C/I rendah. Peningkatan kedua yang dihasilkan AMR adalah pada saat network memberikan kanal Halfrate, yaitu suatu keadaan di mana setelah BTS dan MS mengukur Uplink dan Downlink lalu memberikan kanal AMR HR pada pelanggan tersebut. Keuntungan dari kanal AMR HR ini adalah memiliki codec Halfrate yang lebih baik dari pada yang ada di network yang belum memakai AMR. Dengan codec Halfrate ini, maka pelanggan akan mendapat hasil pengkodean yang bagus sehingga berpengaruh pada rendahnya noise dan peningkatan kualitas suara. Keuntungannya bagi operator adalah meningkatnya pula kapasitas dari kanal suara.

Baik BTS (uplink) maupun MS (downlink) secara terus menerus dan berkesinambungan mengukur kualitas radio atau carrier per interference $(C / I)$ dan berdasarkan dari pengukuran inilah codec rate disesuaikan dengan level interference yang terjadi pada MS dan BTS. Dalam perancangan fitur AMR ini, diperlukan beberapa perubahan dari segi perangkat keras seperti mengganti Tranceiver Unit (TRU) yang dapat menangani fitur ini, membuka fitur AMR pada sisi MSC maupun BSC. Dari sisi perangkat lunak diperlukan BSS release 10 Ericsson, dan yang paling terpenting adalah layanan ini juga harus didukung oleh MS yang compatible dengan fitur ini. Mobile Station/Hand Phone yang harus support pada penerapan fitur ini masih menjadi kendala karena belum semua pelanggan membeli handset yang terbaru dan bisa mengakses fitur ini (Gambar 1).

\section{HASIL DAN PEMBAHASAN}

Data yang diambil dari hasil penerapan AMR pada sistem jaringan GSM ini melalui pengukuran Test Equipment Mobile System (TEMS) dengan mengunci perangkat tersebut kepada satu channel dan membandingkan antara jaringan yang menggunakan fitur AMR dengan tanpa fitur ini. Perangkat yang dipakai dari penerapan fitur menggunakan test lab PT Telkomsel secara life network.

Pengukuran network yang menggunakan AMR diukur dari nilai Speech Quality Index (SQI) selama active call atau panggilan sedang berlangsung. Nilai SQI diambil dari aplikasi TEMS dengan cara Mobile Station melakukan panggilan pada kondisi yang sama, yaitu jarak, BTS, dan frekuensi yang sama. Setelah mendapatkan pengukuran tersebut, lalu dibandingkan dengan network yang tidak menggunakan fitur ini. Perbandingan ini valid karena menggunakan parameter yang sama.

Dari hasil pengukuran dengan menggunakan TEMS investigation, diperoleh hasil pengukuran yang dilaksanakan sebelum dan sesudah penerapan fitur ini. Ada $2 \log$ file yang diukur pada tanggal 27 Juli 2009 sekitar pukul 04:00 PM. Pengukuran tidak bisa kami lakukan lebih lama lagi dikarenakan keterbatasan keamanan untuk memasuki sistem jaringan pada PT Telkomsel.

Speech Quality Index adalah suatu nilai yang dipergunakan dalam menentukan level kualitas suara air interface/saluran udara pada GSM. SQI diukur berdasarkan besarnya interference, BER dan Frame Error Rate (FER). Semakin rendah interference, maka kualitas suara akan meningkat; dan juga semakin sedikit $B E R$, maka semakin bagus SQI-nya. Jika SQI di bawah 5 adalah sangat jelek, kemungkinan error rate-nya sangat besar dan dapat menimbulkan drop call karena kualitas buruk (drop call due

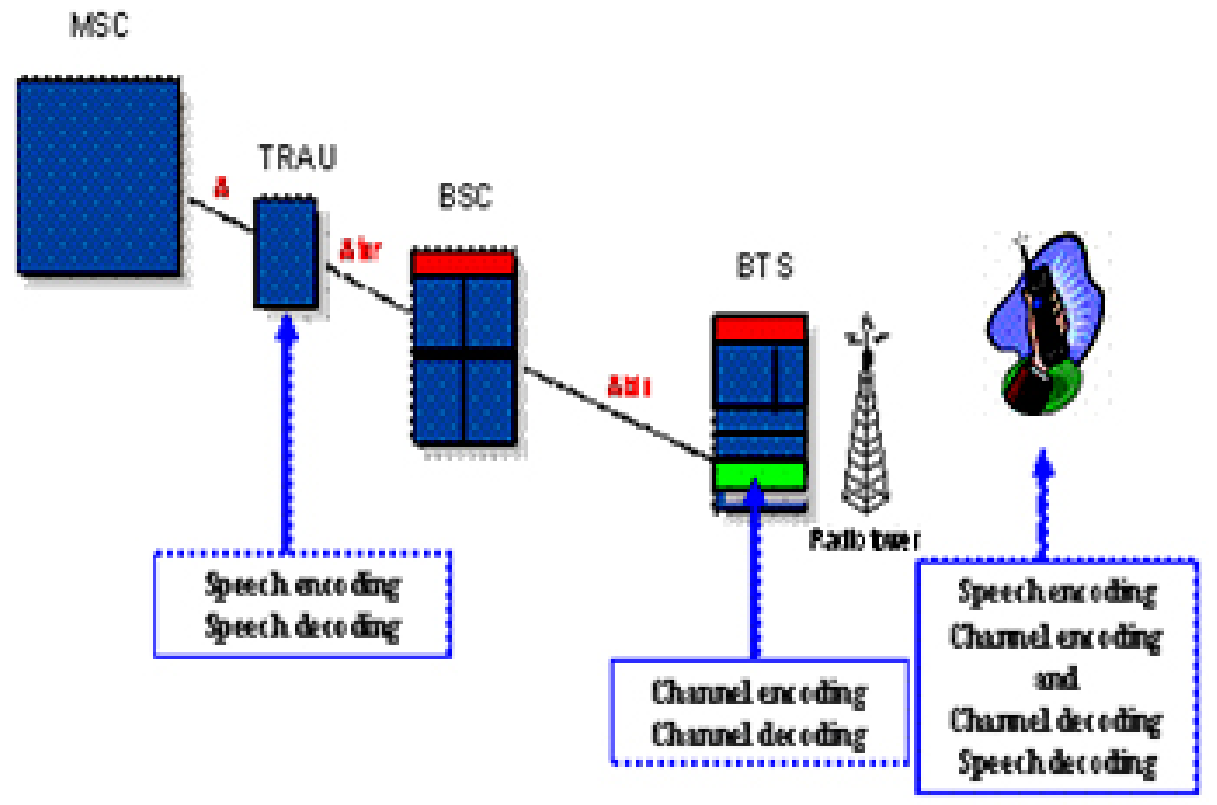

Gambar 1 Penerapan AMR pada GSM 
to bad quality). Sedangkan pada nilai tertinggi yaitu range 20-30 adalah kondisi di mana kualitas jaringan udara dalam keadaan error rate yang rendah, baik dari sisi bit error maupun frame error sehinga SQI akan meningkat.

Pengukuran SQI dilakukan pada 4 jenis kanal yang berbeda sebagai perbandingan antara satu dengan yang lainnya. Semua pengukuran dilakukan dengan menggunakan alat dan jaringan yang sama, tetapi pada jenis kanal yang berbeda. Pengukuran pertama untuk kanal FR, kedua untuk kanal AMR FR, ketiga untuk kanal HR, dan yang terakhir untuk kanal AMR HR. Untuk hasil pengukuran yang lebih akurat, TEMS mengunci satu kanal pada frekuensi tertentu dan tidak bergerak atau berada pada jarak (timing advanced yang sama) dari BTS. AMR hanya berlaku terhadap network yang menerapkan dan mengaktifkan fitur ini, dan hanya handset tertentu yang bisa menggunakan fitur ini. Namun, handphone yang beredar di pasar saat ini rata-rata sudah mendukung untuk fasilitas ini (Gambar 2).

Data yang tertera pada Gambar 2 menerangkan kondisi jaringan sebelum penerapan AMR seperti yang ditunjukkan dalam lingkaran bahwa Speech Quality Index, dengan frekuensi 94 dan cell identity 11401 adalah level 21.

Data yang tertera pada Gambar 3 menerangkan kondisi jaringan setelah penerapan AMR FR seperti yang ditunjukkan dalam lingkaran bahwa Speech Quality Index, dengan frekuensi 94 dan cell identity 11401 adalah level 30. Jika dibandingkan dengan hasil drive tes antara Gambar 2 (sebelum penerapan AMR FR) dan Gambar 3 (setelah penerapan AMR FR). Dengan menggunakan frekuensi dan jarak yang sama, maka dilihat bahwa level SQI meningkat menjadi 30. Peningkatan pada speech quality adalah dampak positif dari penerapan AMR ini. Suara yang didengar dan dikirim akan lebih bersih dan rendah interference. Keuntungan lain dari penerapan ini akan mengurangi drop call karena error (bad quality) yang disebabkan interference dan sinyal yang mengganggu lainnya (Gambar 3).

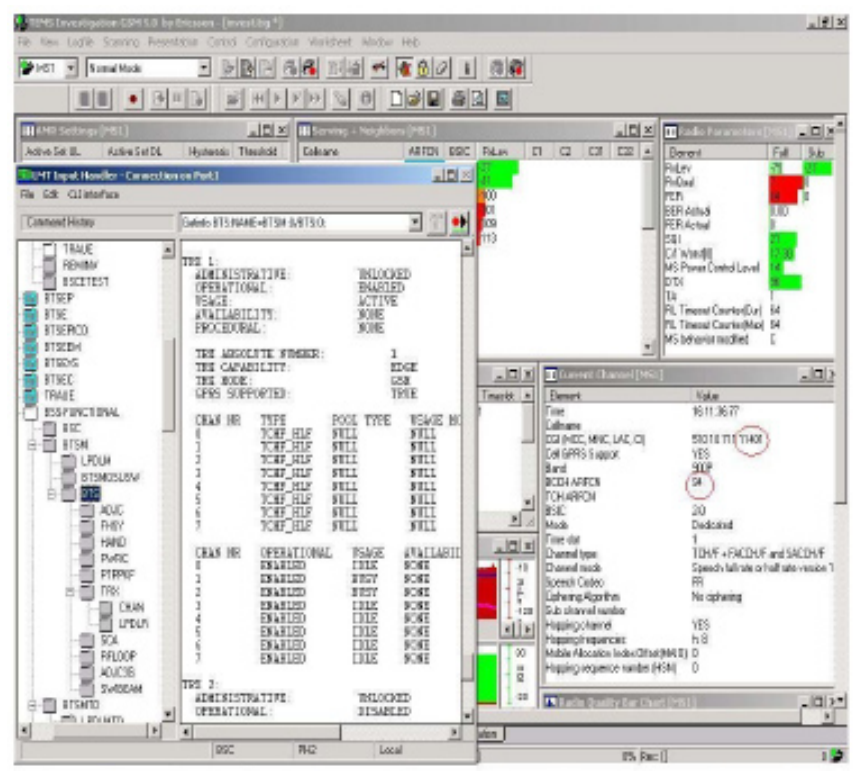

Gambar 2 Data TEMS SQI Call Non AMR Fullrate

Data hasil drive tes menggunakan TEMS dengan frekuensi 94 dan cell identity 11401 pada network yang belum menerapkan AMR halfrate menunjukkan bahwa kualitas suara yang dihasilkan berada pada level 17 (Gambar 4).

Didapat hasil dari drive tes setelah penerapan AMR (Gambar 5) ditunjukkan peningkatan pada speech quality index menjadi 27. Dalam lingkaran merah pada Gambar 5 juga diterangkan tentang jenis kanal dan speech codec, yang digunakan pada saat call sedang berlangsung, yaitu halfrate. Kanal halfrate yang mempunyai keuntungan dari segi kapasitas dengan kualitas suara yang tinggi (excellent) membuat fitur AMR ini sangat menguntungkan, dari sisi pelanggan dan penyedian jasa telkomunikasi serta merupakan suatu terobosan dalam dunia telekomunikasi dengan menggunakan sistem perubahan speech coding dan channel coding.

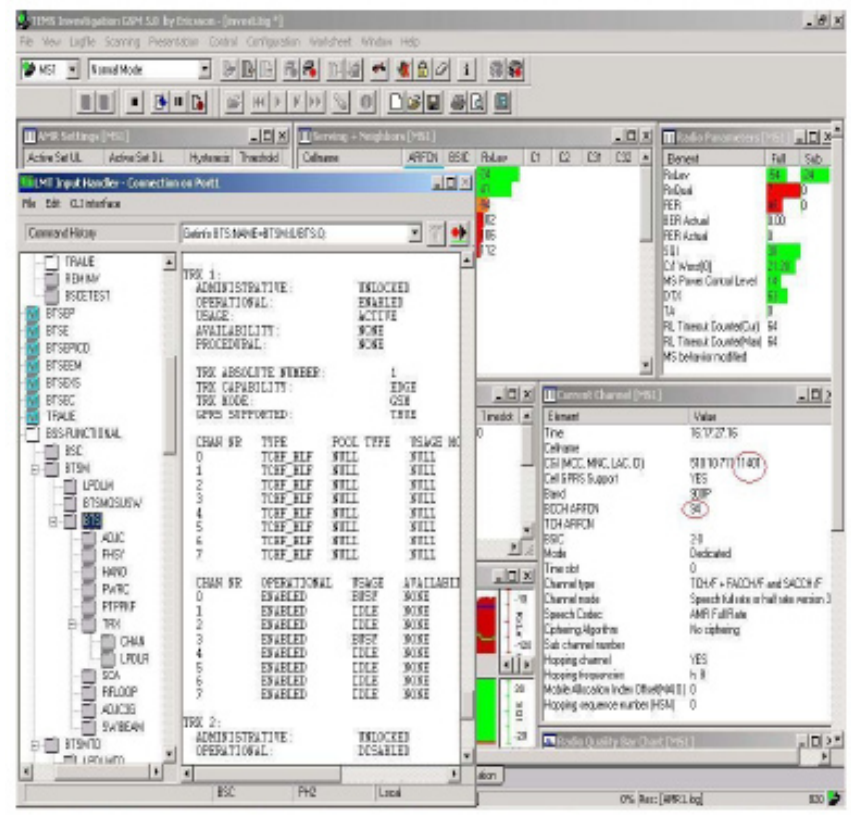

Gambar 3 Data TEMS SQI Call AMR Fullrate

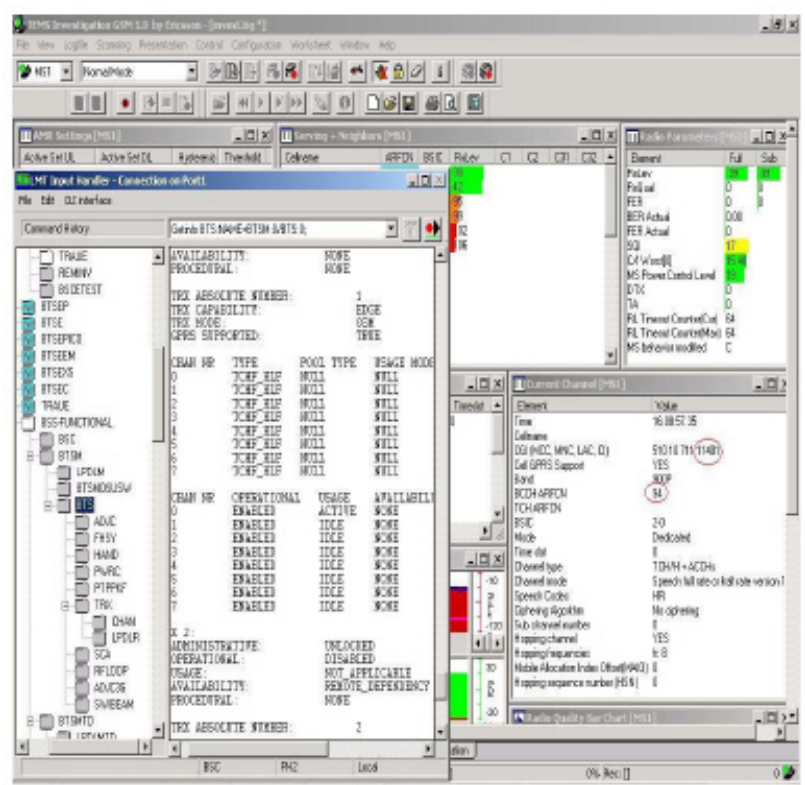

Gambar 4 Data TEMS SQI Call Non Amr Halfrate

Pada kondisi tidak menggunakan fitur AMR, kanal Fullrate membagi $16 \mathrm{kbps}$ voice menjadi $13 \mathrm{kbps}$ dan $3 \mathrm{kbps}$ untuk signaling (kanal pengontrol). Pembagian ini bersifat tetap dan mengikuti standard spesifikasi GSM. Namun, pada fitur AMR kanal fullrate, pembagian antara error correction dan voice dapat dibagi menurut level interference pada network sehingga Speech Quality Index yang didapat akan mencapai maksimal dan meredam seminimal mungkin noise akibat interference. 


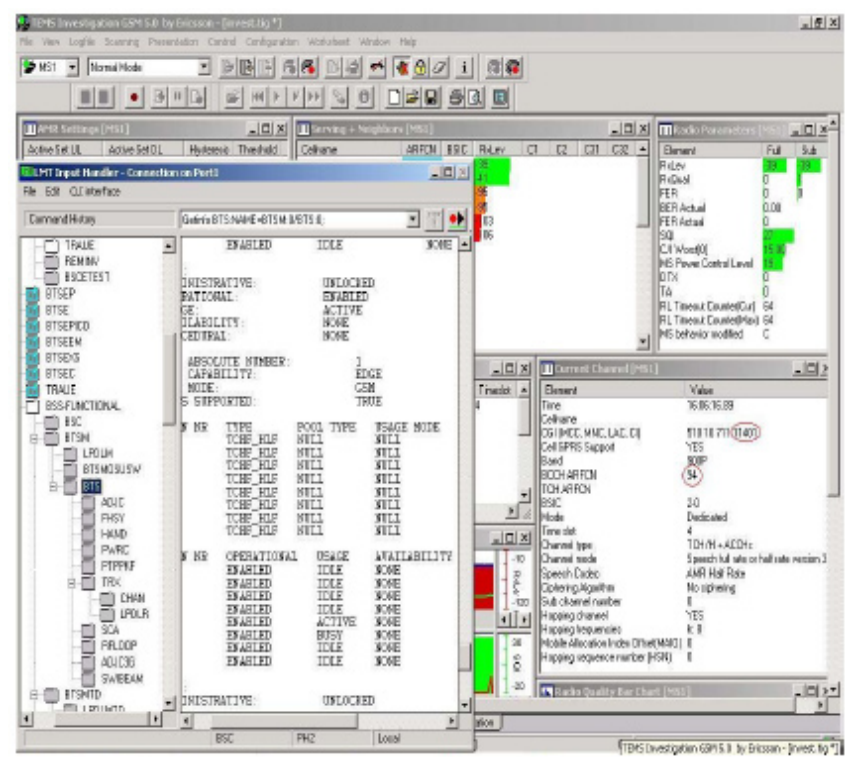

Gambar 5 Data TEMS SQI Call AMR Halfrate

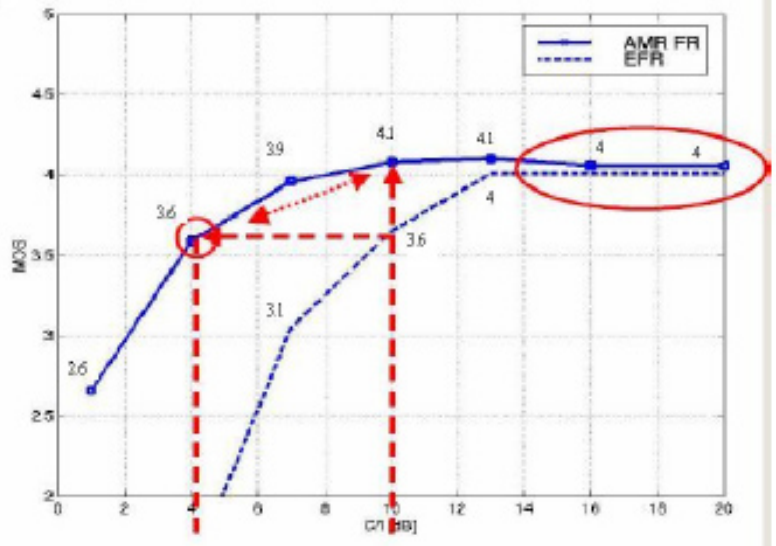

Gambar 6 Perbandingan Kanal EFR dan AMR Fullrate

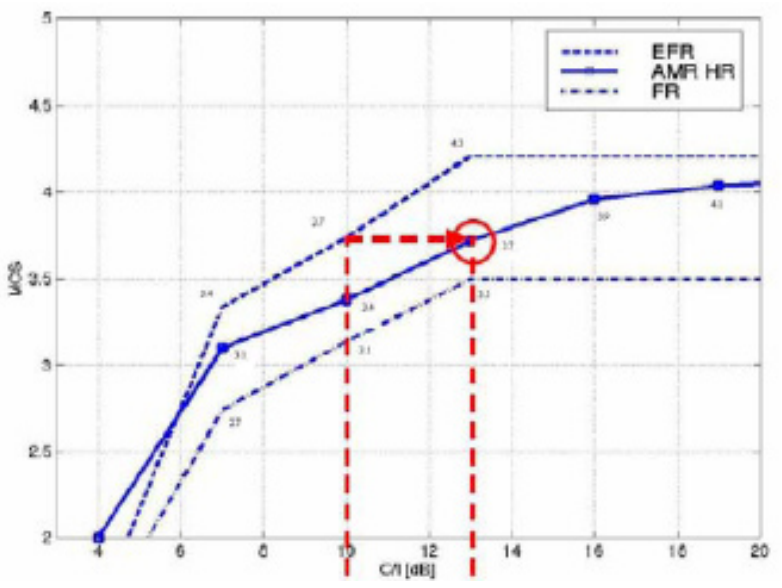

Gambar 7 Perbandingan Kanal EFR dan AMR Halfrate

Pada Gambar 7, garis merah merupakan perbandingan level C/I tertentu dengan nilai MOS yang didapatkan. Sekarang kita bandingkan antara 3 jenis kanal pada C/I yang sama. Pada saat C/I $10 \mathrm{~dB}$, maka pada kanal FR nilai MOS yang didapat adalah 3.1. Pada kanal AMR HR, nilai MOS yang didapatkan 3.4; sedangkan pada kanal EFR, nilai MOS yang didapatkan 3.7 .
Sedangkan untuk perbandingan 2 jenis kanal, kanal AMR HR saat C/I $13 \mathrm{~dB}$ nilai MOS yang didapat 3.7, dengan nilai C/I yang sama pada kanal FR nilai MOS yang didapat 3.5 . Perbandingan-perbandingan ini menerangkan bahwa kualitas AMR Halfrate tidak dapat menyamai Enhanced Fullrate, walaupun dalam kondisi yang sempurna (interference rendah). Tetapi, dilihat dari grafik bahwa speech quality AMR Halfrate lebih baik dari kanal voice fullrate standar (tanpa fitur AMR). AMR halfrate lebih baik juga dalam penyediaan kanal dan kualitas suara, dibandingkan dengan halfrate yang standar dan merupakan metode yang sangat handal dalam peningkatan kapasitas kanal dan kualitas suara.

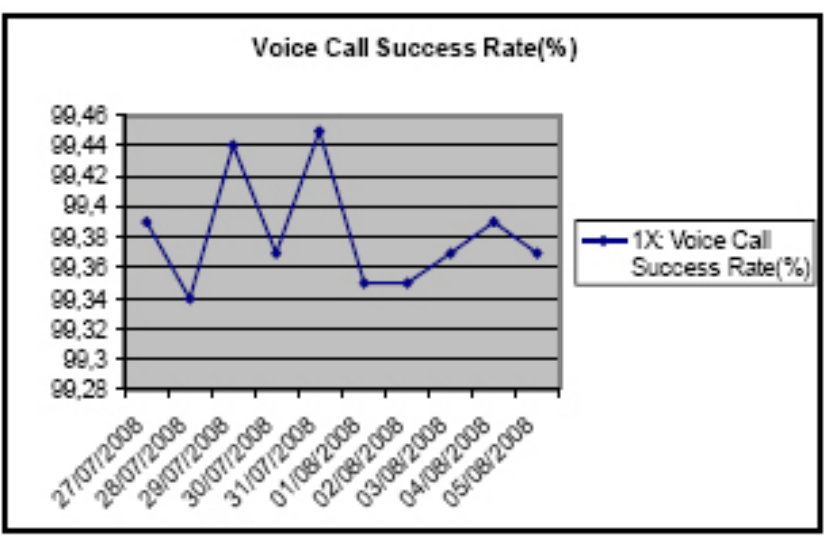

Gambar 8 Statistik Call Success Rate pada BTS AMR

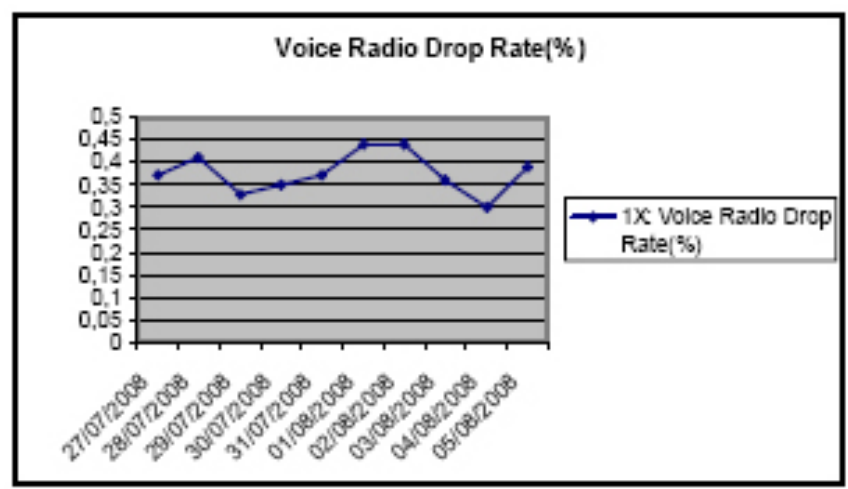

Gambar 9 Statistik Call Drop Rate pada BTS AMR

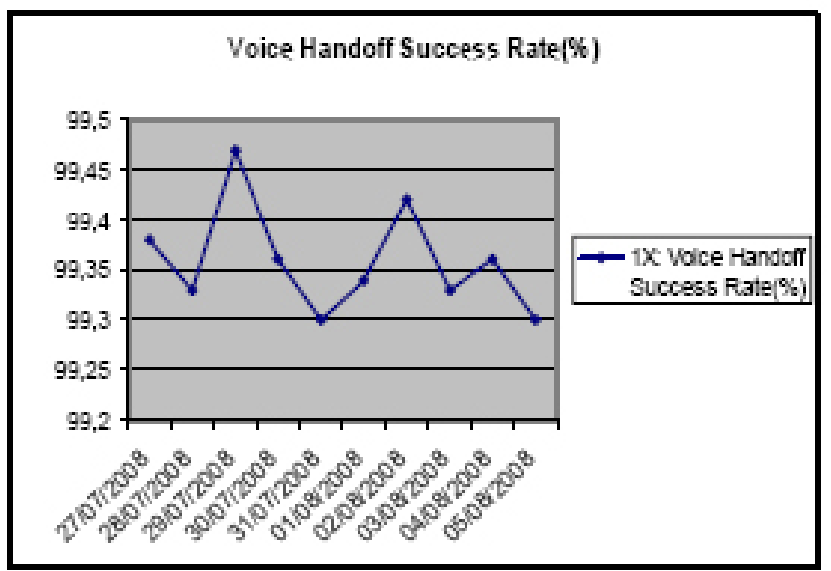

Gambar 10 Statistik Handover Success Rate pada BTS AMR

Dari Gambar 8 sampai dengan Gambar 10, dapat dilihat bahwa tingkat call success dan handover success di 
atas 99\%, dan untuk call drop nya masih di bawah 0,5\% dari seluruh traffic yang ada pada BTS tersebut. Peningkatan Speech Quality Index pada saat penerapan AMR Fullrate sangat signifikan, dilihat dari hasil drive tes pada network yang diukur sebelum dan sesudah pengaktifan fitur ini. Telah diperlihatkan pada Gambar 3 bahwa SQI meningkat sebesar 9 level SQI. Nilai SQI 30 yang tertera dari hasil penerapan AMR Fullrate tersebut dimasukkan dalam kategori excellent.

Level SQI 21 yang didapat dari jaringan dengan tidak menggunakan AMR dan level 30 dengan fitur AMR FR diukur dengan parameter frekuensi, timing advanced (jarak) dan perangkat yang sama. Diharapkan pengukuran dan perbandingan ini menghasilkan merepresentasikan keadaan yang sebenarnya. Dengan peningkatan mendekati 40\%, maka dipastikan akan adanya perbedaan penerimaan pada sisi pelanggan, di mana suara yang ditransmit dan diterima akan lebih bersih, jernih, dan dengan level interference yang minim.

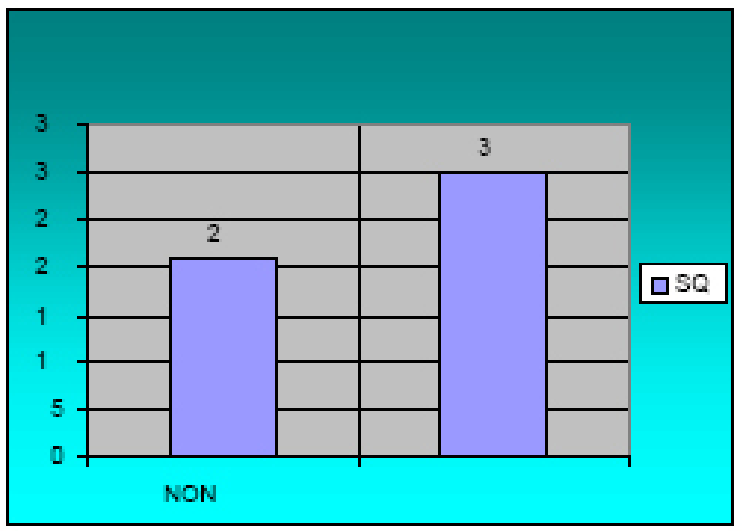

Gambar 11 Perbandingan SQI AMR pada Fullrate

Sebelum diaktifkan AMR pada network, maka pengukuran pre-test dilakukan yaitu mengambil data kondisi pada jaringan selengkap mungkin, baik dari sisi alarm perangkat, kinerja cell, dan status masing-masing Network Element untuk mengetahui kondisi jaringan yang ada. AMR Halfrate yang sangat menguntungkan operator dalam sisi kapasitas sehingga lebih banyak pelanggan dapat memakai jaringan yang tersedia. Peningkatan kapasitas yang dihasilkan oleh penerapan halfrate ini tanpa diperlukan perangkat keras yang banyak. Meningkatnya kapasitas dengan angka 100\% atau 2 kali lipat, diharapkan AMR halfrate tetap menjaga sisi kualitas suara.

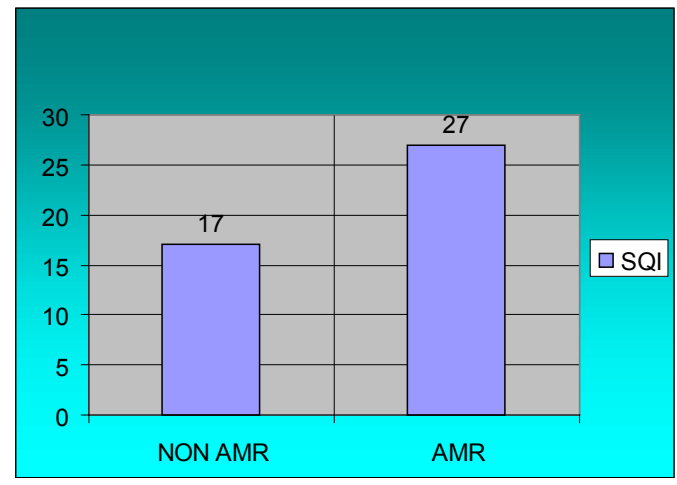

Gambar 12 Perbandingan SQI AMR Pada Halfrate

Dari Gambar 8, diterangkan bahwa Speech Quality yang dihasilkan sebelum diterapkan AMR berada pada level
"Good" yaitu 17, dengan level interference rendah. Level "Good" berada pada range 15-19. Sedangkan setelah AMR halfrate diterapkan, Speech Quality Index naik menjadi level "excellent" yaitu range 20-30. Dengan demikian, peningkatan SQI mencapai hampir 60\% sehingga suara yang dihasilkan menjadi bagus dan jernih.

\section{SIMPULAN}

Berdasarkan hasil pengukuran dan analisis yang telah dilakukan terkait dengan penerapan fitur AMR FR dan AMR HR pada jaringan GSM, maka dapat diambil beberapa kesimpulan, yaitu (1) Pada kanal AMR FR, peningkatan nilai SQI sekitar 40\%. Dibandingkan dengan kanal FR, di mana suara yang terdengar maupun yang didengar jauh lebih baik dengan tingkat gangguan yang rendah; (2) Kualitas kanal AMR FR dapat menyamai kualitas kanal EFR dalam tingkat luar biasa (excellent) dan kualitas suara kanal AMR FR masih lebih baik daripada kanal EFR, pada saat tingkat gangguan tinggi (level C/I rendah); (3) Pada kanal AMR HR, peningkatan nilai SQI hampir mencapai $60 \%$ dibandingkan dengan kanal HR. Dengan begitu, kanal ini dapat menyamai kualitas kanal FR dalam tingkat luar biasa (excellent); dan (4) Jika dibandingkan antara kanal EFR dan FR, maka kanal AMR HR berada dalam posisi moderate dalam hal kualitas suara. Kanal AMR HR juga memiliki kelebihan lain, yaitu dapat menyediakan kapasitas kanal suara 2 kali lipat daripada kanal EFR maupun FR.

Penelitian ini merupakan salah satu cara dalam peningkatan kinerja dan kualitas jaringan GSM yang mungkin masih belum sempurna. Namun, penelitian lebih lanjut diharapkan dapat menyempurnakannya dan mendapatkan hasil yang lebih baik dengan error yang lebih kecil. Untuk tujuan itu, maka diberikan saran sebagai berikut (1) Digunakan berbagai macam model jaringan (misalnya CDMA, Wimax dan lainnya) yang bisa digunakan sebagai perbandingan untuk mendapatkan hasil kualitas suara yang maksimal; (2) Waktu pengukuran yang lebih lama agar bisa mendapatkan parameter-parameter lainnya, yang bisa digunakan untuk meningkatkan kualitas dan kapasitas kanal suara dari segi lain; dan (3) Pemilihan parameter jaringan dibuat dengan variasi lain seperti data history traffic yang digunakan lebih dari 2 hari (2x24 jam) yang lalu, parameter pendukung yang lebih lengkap seperti traffic maksimum, kapasitas trunk BTS, dan sebagainya.

\section{DAFTAR PUSTAKA}

Halonen, T., Romero, J., and Melero, J. (2002). GSM, GPRS and EDGE performance, Wiley.

MiHa. (2002). A wireless architecture for a multimedia world. Retrieved from http://www.gsmworld.com/news/media_2002/ short.pdf. The Journal of the Communication Network, 1(1).

Mulyanta, E. (2003). Kupas tuntas telepon selular, Yogyakarta: Penerbit Andi.

Nokia. (2002). NOKIA EDGE, Solution Description.

Scourias, J. (1999). Overview of the global system for mobile communications. Retrieved from http://ccnga.uwaterloo. ca/ jscouria/GSM/gsmreport.html.

UMTS Forum. (2005). White paper from UMTS Forum, 3G/ UMTSTowards mobile broadband and personal Internet. Retrieved from http://www.umts-forum.org/servlet/dycon/ ztumts/umts/Live/en/umts/MultiMedia_PDFs_Papers_ Towards-Mobile-Broadband-Oct05.pdf. 